\title{
Jejunum and Ileum Neuroendocrine Tumor pNX TNM Finding v8
}

National Cancer Institute

\section{Source}

National Cancer Institute. Lejunum and Ileum Neuroendocrine Tumor PNX TNM Finding v8. NCI Thesaurus. Code C135115.

Jejunum and ileum neuroendocrine tumor in which the regional lymph nodes cannot be assessed. (from AJCC 8th Ed.) 